\title{
Suspended Sediment Transport in the Freshwater Reach of the Hudson River Estuary in Eastern New York
}

\author{
G. R. Wall $\cdot$ E. A. Nystrom $\cdot$ S. Litten
}

Received: 27 November 2007 / Revised: 26 February 2008 / Accepted: 12 April 2008/Published online: 15 May 2008

(C) Coastal and Estuarine Research Federation 2008

\begin{abstract}
Deposition of Hudson River sediment into New York Harbor interferes with navigation lanes and requires continuous dredging. Sediment dynamics at the Hudson estuary turbidity maximum (ETM) have received considerable study, but delivery of sediment to the ETM through the freshwater reach of the estuary has received relatively little attention and few direct measurements. An acoustic Doppler current profiler was positioned at the approximate limit of continuous freshwater to develop a 4-year time series of water velocity, discharge, suspended sediment concentration, and suspended sediment discharge. This data set was compared with suspended sediment discharge data collected during the same period at two sites just above the Hudson head-of-tide (the Federal Dam at Troy) that together represent the single largest source of sediment entering the estuary. The mean annual suspended sedimentdischarge from the freshwater reach of the estuary was 737,000 metric tons. Unexpectedly, the total suspended sediment discharge at the study site in November and December slightly exceeded that observed during March and April, the months during which rain and snowmelt typically result in the largest sediment discharge to the estuary. Suspended sediment discharge at the study site exceeded that from the Federal Dam, even though the intervening reach appears to store significant amounts of
\end{abstract}

G. R. Wall $(\square) \cdot$ E. A. Nystrom

US Geological Survey New York Water Science Center,

425 Jordan Rd.,

Troy, NY 12180, USA

e-mail: grwall@usgs.gov

S. Litten

New York State Department of Environmental Conservation, 625 Broadway,

Albany, NY 12233, USA sediment, suggesting that $30-40 \%$ of sediment discharge observed at the study site is derived from tributaries to the estuary between the Federal Dam and study site. A simple model of sediment entering and passing through the freshwater reach on a timescale of weeks appears reasonable during normal hydrologic conditions in adjoining watersheds; however, this simple model may dramatically overestimate sediment delivery during extreme tributary high flows, especially those at the end of, or after, the "flushing season" (October through April). Previous estimates of annual or seasonal sediment delivery from tributaries and the Federal Dam to the ETM and harbor may be high for those years with extreme tributary highflow events.

Keywords Hudson river - Suspended sediment .

Suspended sediment discharge - Tidal freshwater - Estuary .

New York Harbor · Resuspension · Sediment transport .

ADCP. Poughkeepsie

\section{Introduction}

The Hudson River extends $507 \mathrm{~km}$ from its headwaters in the Adirondack Mountains of New York State to the Atlantic Ocean. The lower $246 \mathrm{~km}$ of the river from the Federal Dam at Troy, NY to the Battery in New York City (Fig. 1) is tidal. The Hudson River discharges to New York Harbor, which is one of the largest harbors in the world and brings billions of dollars to the region's economy (Port Authority of NY/NJ 1995). Millions of dollars are spent annually in dredging operations to remove sediment and maintain shipping lanes; therefore, information on the amounts of sediment discharged from the estuary and the relation between watershed delivery and estuary sediment 
transport should help efforts to manage the harbor. Recent work by Geyer et al. (2001), Woodruff et al. (2001), and Traykovski et al. (2004) discuss watershed inputs to the Hudson estuary turbidity maximum (ETM) in the context of what enters the estuary at the Federal Dam. These studies offer a simplified view of sediment transport through the freshwater reach necessitated by the lack of observational data in this reach. Panuzio (1965) and Olsen (1979) used measured river concentrations at Poughkeepsie and near Piermont respectively, along with both measured and estimated water discharge from the Federal Dam and intervening tributaries to estimate an annual sediment discharge for the Hudson. Ellsworth (1986) identified the relative importance of sources and sinks of sediment in the tidal Hudson concluding that river bank erosion contributed less than $1 \%$ of the total fine-grained sediment discharge. Subsequent modeling efforts by Howarth et al. (1991), Swaney et al. (1996), Lodge (1997), Woodruff (1999), and Farley et al. (2003) used a variety of modeling techniques to derive estimates of watershed sediment delivery to the Hudson.

In 2002, the US Geological Survey, in cooperation with the New York State Department of Environmental Conservation, began a study to (1) provide a continuous record of water discharge, suspended sediment concentration, and suspended sediment discharge at the freshwater limit of the estuary and (2) provide insight into the timing and mechanisms responsible for the transport and storage of suspended sediment in and through the freshwater reach of the estuary. This paper details observations from the first 4 years of this effort.

\section{Study Location}

The study site is located $3.7 \mathrm{~km}$ south of Poughkeepsie, NY (Fig. 1) and 116 river kilometers north of the Battery in New York City. The river here is $\sim 18 \mathrm{~m}$ deep with steep banks and a nearly flat bottom over its $800-\mathrm{m}$ width. The river bottom is cohesive estuarine clay with isolated pockets of fluid-rich clay and mud. Recovery of coal slag in bottom samples throughout the site cross section, presumably dumped overboard from steamboats that were used on the river for 150 years until the mid-1950s, indicate that the reach is presently non-depositional. The river is subject to a semi-diurnal tide with a mean tidal range of $0.95 \mathrm{~m}$ (Center for Operational Oceanographic Products and Services 2007). The position of the estuarine salt front is primarily dictated by freshwater input to the tidal river (Abood 1974) and typically varies between 30 and $90 \mathrm{~km}$ upstream from the Battery (Geyer and Chant 2006). The study site experiences brackish conditions only during periods when the net river discharge (and hence net sediment discharge) is extremely low, and for the purpose of this study, this location is considered to be the mouth of the freshwater tidal river. The watershed area above the site is $30,406 \mathrm{~km}^{2}$ of which $69 \%\left(20,953 \mathrm{~km}^{2}\right)$ lies above the Federal Dam (US Geological Survey 2006). The site is downstream from the majority of tributaries entering the estuary with the total Hudson River watershed area (at the Battery) covering $34,450 \mathrm{~km}^{2}$.

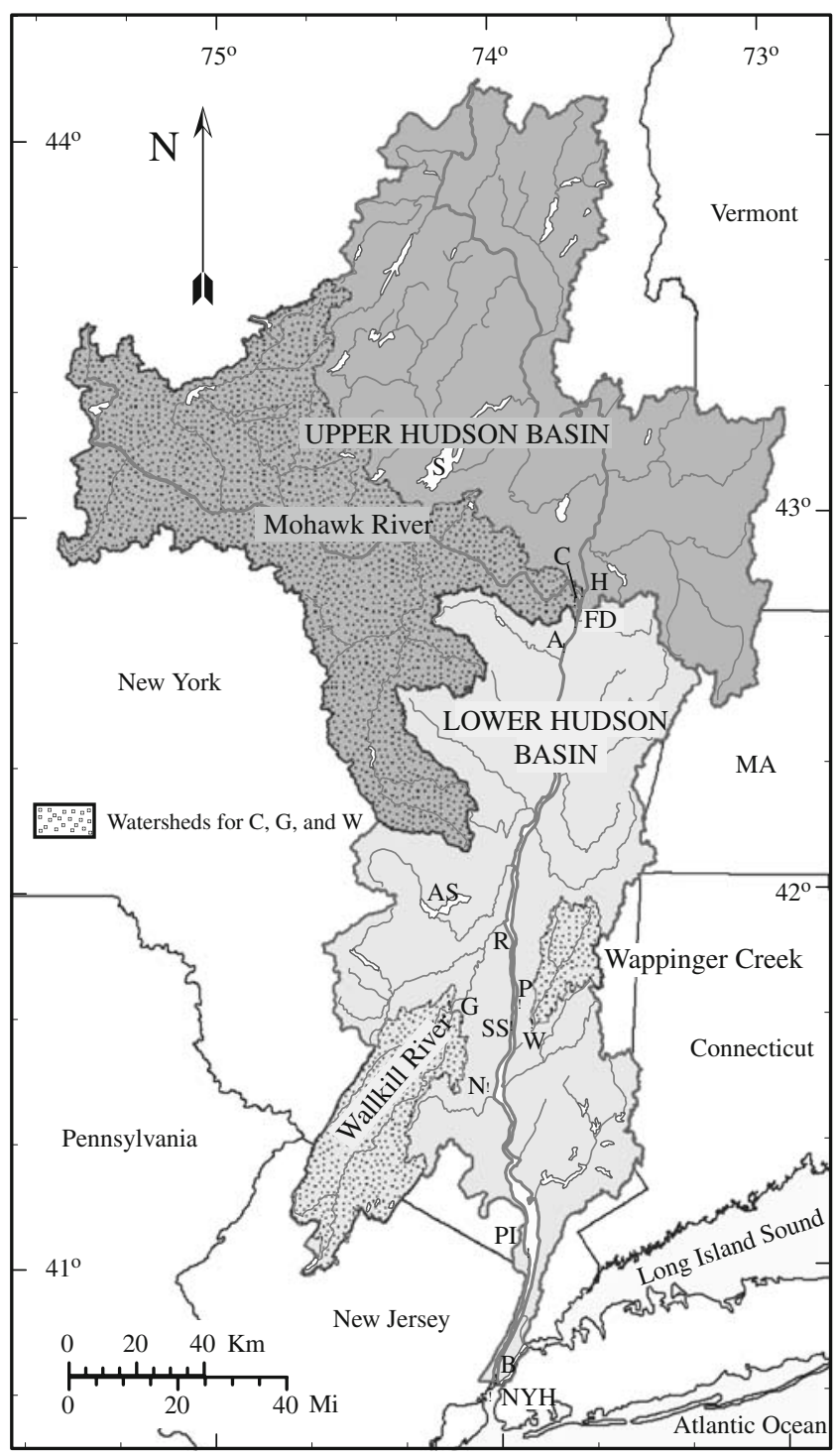

Base from U.S. Geological Survey digital data, 1983, 1;100,000

Universal Transverse Mercator Projection

Fig. 1 Locations of pertinent sites within Hudson River Basin, NY. A Albany, $A S$ Ashokan Reservoir, $B$ The Battery at New York City, $C$ Mohawk River at Cohoes (USGS site 01357500), FD Federal Dam and Hudson River head-of-tide, $G$ Wallkill River at Gardiner (USGS site 01371500), $H$ Hudson River at Waterford (USGS site 01335770), $N$ Newburgh, NYH New York Harbor, $P$ Poughkeepsie, PI Piermont, $R$ Rondout River mouth, $S$ Sacandaga Reservoir, $S S$ study site, Hudson River Below Poughkeepsie (USGS site 01372058), W Wappinger Creek near Wappinger Falls (USGS site 01372500) 


\section{Methods}

Suspended sediment discharge was computed at the study site using data from an acoustic Doppler current profiler (ADCP). Input of suspended sediment to the estuary at the Federal Dam was computed as the sum of suspended sediment discharge computed from two sites directly upstream from the dam. To place our observations in context, an analysis was performed of runoff conditions in the watershed above and below the Federal Dam both before and during the study period.

\section{Suspended Sediment Concentration}

Echo intensity and velocity data from an upward-looking acoustic Doppler current profiler were used to determine suspended sediment concentration (SSC) every $15 \mathrm{~min}$ at the study site for the period July 1, 2002 to June 30, 2006. A detailed description of the computational and calibration methods used can be found in Wall et al. (2006). In brief, echo intensity was corrected for acoustic energy loss with distance from the ADCP transceivers due to beam spreading and water attenuation. Normalizations to echo intensity were made for changes in transmit power and transmit length during ADCP deployments along with adjustments to account for beam-to-beam variability in measures of echo intensity. ADCP estimates of SSC in the full-river crosssection were used to adjust estimates from the upwardlooking location to conditions in the full cross-section. The relation between corrected echo intensity data and SSC was developed from boat-mounted measures of echo intensity at a given depth cell and concurrent sample collection using a P-61 point-integrating water sampler at the same depth.

\section{Water Discharge}

Discharge at the study site was determined at the same frequency as SSC using a multiple regression relation between environmental measures and water discharge measured by a boat-mounted ADCP. Flood current discharge was significantly $(p<0.01)$ correlated with the combined measures of depth-averaged velocity measured by the upward-looking $\mathrm{ADCP}$ and wind stress; river stage was an additional factor for the ebb-current discharge. Net (downstream) discharge computation entailed processing the 15 -min data with a lowpass digital filter to remove the semi-diurnal tidal signal. The filter is a fast Fourier transform set to remove fixedfrequency signals with a period of less than $30 \mathrm{~h}$.

\section{Suspended Sediment Discharge}

Instantaneous suspended sediment discharge at the study site was computed as the product of SSC and the corresponding water discharge (unfiltered). The resulting time series was in turn processed by the same low-pass filter as was done with water discharge to produce a net suspended sediment discharge. Each filtered value was assumed to represent the instantaneous suspended sediment discharge at any time over the next $15 \mathrm{~min}$; therefore, each filtered value was multiplied by 15 , and the summation of all 96 resulting values for each day constituted the daily net suspended sediment discharge.

The amount of suspended sediment entering the estuary at the Federal Dam was computed as the sum of suspended sediment discharge computed at two sites directly upstream from the Federal Dam - the Mohawk River at Cohoes (USGS Station 01357500) and the Hudson River at Waterford (01335770). The combined watersheds represent 99.7\% of the Hudson River drainage above the dam; thus, their combined suspended sediment discharge is considered representative of the entire upper Hudson River Basin (Fig. 1). Daily suspended sediment samples from the Waterford site were collected from a bridge-mounted depth-integrating isokinetic water sampler; those from the Cohoes site were collected using an automatic pumping water sampler programmed for high-flow sample collection in addition to fixed-interval sampling during baseflow periods. Periodic equal-width increment or equal-discharge increment sampling (USGS 1999) at both sites allowed for data corrections to account for differences between observed concentrations at the sampler locations and in the river cross-section. Daily suspended sediment discharge at each site was computed by methods of Potterfield (1972).

\section{Watershed Conditions}

To compare watershed conditions before and during the study period, runoff (in millimeters) was computed by normalizing USGS daily mean water discharge data by watershed area for three sites-Wappinger Creek near Wappinger Falls (01372500), the Wallkill River at Gardiner (01371500), and the Mohawk River at Cohoes (Fig. 1). These sites were selected due to their geographic position and the availability of long-term and continuous water discharge data dating back to 1929. An average of the Wallkill River and Wappinger Creek daily runoff values was considered representative of watershed conditions in the lower Hudson Basin, and runoff data from the Mohawk site were considered representative of conditions in the upper Hudson Basin.

\section{Results}

Water Discharge

The 15-min discharge values at the study site ranged between an ebb-current maximum of $11,910 \mathrm{~m}^{3} \mathrm{~s}^{-1}$ on 
December 6, 2003 to a flood current maximum of $10,900 \mathrm{~m}^{3} \mathrm{~s}^{-1}$ on September 10, 2002. The maximum 15min net discharge of $5,350 \mathrm{~m}^{3} \mathrm{~s}^{-1}$ was recorded on April 3, 2005 during that year's spring freshet event. The maximum discharge range for a given day was $20,190 \mathrm{~m}^{3} \mathrm{~s}^{-1}(10,050$ to $-10,140 \mathrm{~m}^{3} \mathrm{~s}^{-1}$ ) on December 24, 2003, and the minimum was $8,330 \mathrm{~m}^{3} \mathrm{~s}^{-1}\left(3,570\right.$ to $\left.-4,760 \mathrm{~m}^{3} \mathrm{~s}^{-1}\right)$ on January 30,2004 . The mean daily net discharge at the study site was $585 \mathrm{~m}^{3} \mathrm{~s}^{-1}$ compared with $476 \mathrm{~m}^{3} \mathrm{~s}^{-1}$ recorded at the Federal Dam over the same period. The daily maximum net discharge is presented as a percentage of the daily maximum ebb discharge by month in Fig. 2. Contrary to the interpretation by Cooper et al. (1988) of Darmer (1969) and Busby (1966) (studies at Poughkeepsie) that high freshwater flows (i.e., net discharge) are no more than $10 \%$ of tidal discharge, we observed that more than half the days in November, February, March, and May and more than $75 \%$ of the days in December, January, and April net discharge exceeded $10 \%$ of tidal discharge (Fig. 2), and on 3 days, the maximum ebb flow exceeded the maximum net flow by less than a factor of 2 . The magnitude of net discharge observed at the study site primarily reflects watershed runoff, although short-term (a few days) fluctuations on the order of hundreds of cubic meters per second were observed to correspond with atmospherically induced sea-level changes that propagated up estuary. Flushing of the freshwater reach up estuary from the study site was calculated from an estimated reach volume of $0.71 \mathrm{~km}^{3}$ (Nitsche et al. 2007) and the cumulative net discharge at the study site, which indicate that the reach flushed approximately 104 times over the 4-year period.

\section{Watershed Runoff}

Daily mean runoff in both the upper and lower Hudson Basins during the study period was significantly higher (Wilcoxan rank-sum test $p<0.001$ ) during October-January than over the same months during the 1929-2002 period (Fig. 3). The median values for these months ranged from

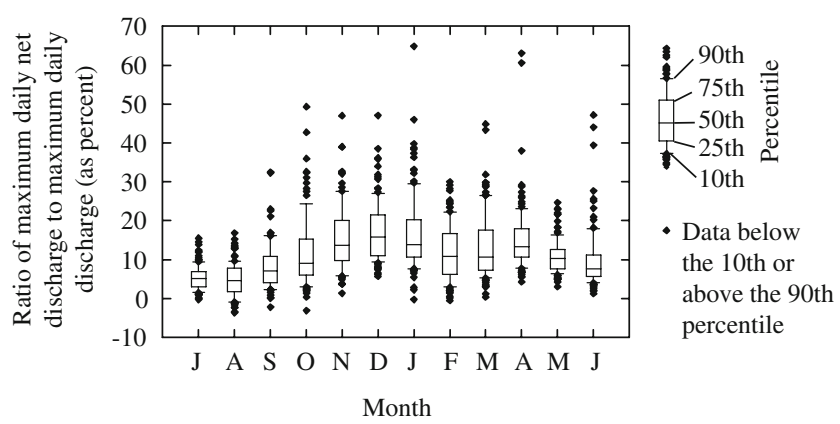

Fig. 2 Monthly distributions of the ratio of maximum daily discharge to maximum daily net discharge recorded at the study site, July 2002 through June 2006 (site location is shown in Fig. 1)
$58.4 \%$ to $349 \%$ higher during the study period as determined using the Hodges-Lehmann estimator (Helsel and Hirsch 1992). June values for the study period were also significantly higher than for the period 1929-2002, but the absolute difference in the medians was small relative to those from October to January and was slightly skewed by an exceptionally large stormflow in June 2006. Spring runoff from the lower Hudson River Basin during the study period was significantly lower for March $(p<0.001)$ compared with the 1929-2002 period. The lower Hudson Basin contributed $19 \%$ of water discharge at the study site computed as the difference in mean daily values from the study site and Federal Dam. Similarly, 19\% was also computed based on the yields derived from Wappinger Creek, Wallkill, and Mohawk Rivers; these values are slightly lower than the $28 \%$ determined from data in Randall (1996) over the period 1951 to 1980.

\section{Suspended Sediment Concentration}

Suspended sediment concentration at the study site ranged seasonally from summer lows of $<10 \mathrm{mg} \mathrm{l}^{-1}$ to winter highs around $100 \mathrm{mg} \mathrm{l}^{-1}$ (Fig. 4). The concentration range associated with daily resuspension due to tides was approximately $20 \mathrm{mg} \mathrm{l}^{-1}$ in summer and $40 \mathrm{mg}^{-1}$ in winter. The percent fines $(<62 \mu \mathrm{m})$ observed in samples collected at the study site over a wide range of tidal and seasonal conditions was $96 \pm 3 \%$ (Wall et al. 2006). Concentration varied fortnightly with the spring-neap cycle of tides, and peak concentration lagged up to 2 days after the new or full moon. Winter concentrations were approximately $20 \mathrm{mg}^{-1}$ higher during the spring tide than the neap tide, but this difference during the summer fell to around $5 \mathrm{mg}^{-1}$. The maximum observed concentration was on Dec. 24, 2003; this occurred 1 day after a new moon, 2 days after the winter solstice, and on the rising limb of a net water discharge peak on December 25th. Peak depth-averaged ebb-current velocities during some of the largest high flows (Fig. 5) were only about 15\% higher than they would have been during normal conditions despite roughly fivefold increases in net water discharge; the corresponding ability to resuspend sediment was thereby only minimally additive to the diurnal tidal energy. Tributary inflow that is great enough to produce a clear increase in ebb-current velocities appears to affect the magnitude of the ebb current most strongly just before the peak net water discharge (Fig. 5); however, this period is small (a few hours) relative to the duration of the net water discharge event, and therefore, the duration of increased potential for resuspension is similarly small over the course of the event.

Suspended sediment concentration peaks typically occur four times daily and lag the ebb and flood-current velocity 
Fig. 3 Monthly and total distributions of normalized daily runoff, 1929-2002 and 200206: Upper Hudson River basin, represented by Mohawk River at Cohoes (USGS site 01357500). Lower Hudson River basin, represented by the mean for two sites-Wappinger Creek near Wappinger Falls (USGS site 013572500) and Wallkill River at Gardiner (USGS site 0137500; locations are shown in Fig. 1)

Fig. 4 Instantaneous (15-min) and tidal-filtered suspended sediment concentration data from the study site and the average instantaneous runoff (normalized for drainage area) from the Mohawk River at Cohoes, Wallkill River at Gardiner, and Wappinger Creek near Wappinger Falls for each of the 4 years of study, 2002-2006 (site locations are shown in Fig. 1)

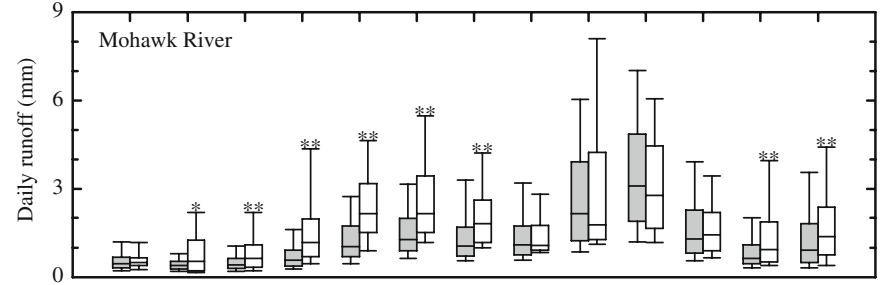

$\square$ 1929-2002 $\square$ 2002-2006

T 90th

1 75th

25th 20 th

$\perp 10$ th

** Median value is significantly higher $(\mathrm{p}<0.001)$

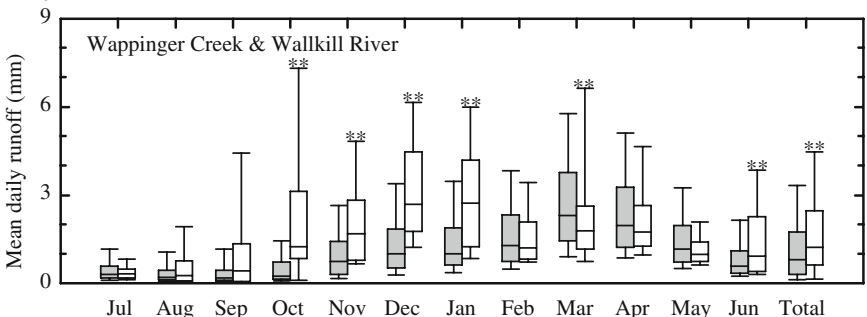

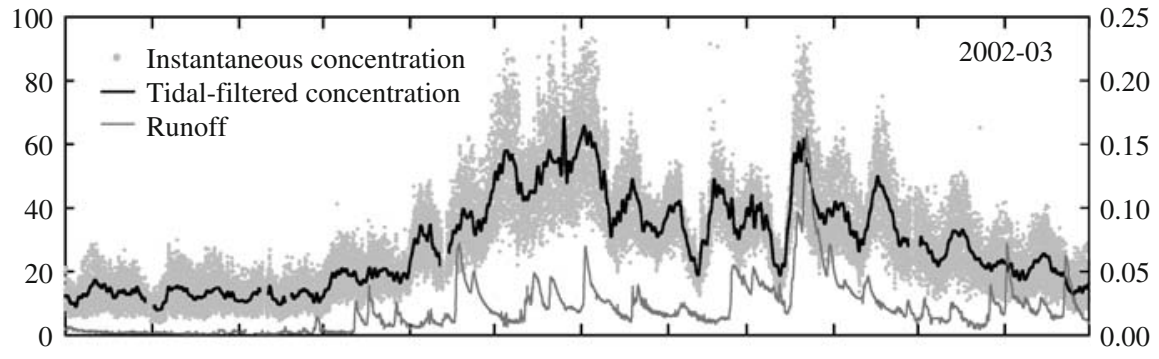
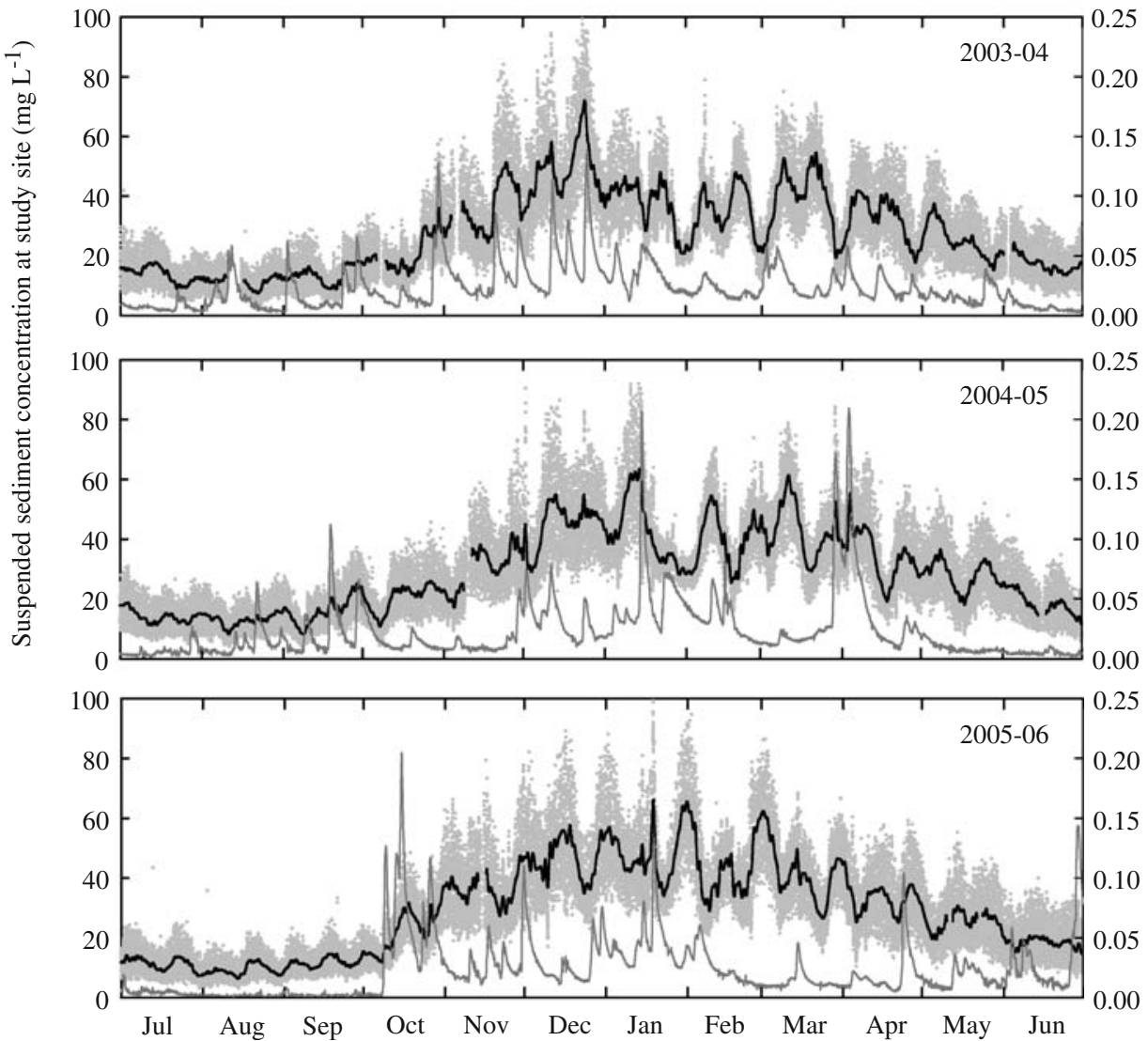
Fig. 5 Water velocity, suspended sediment concentration, and net discharge at study site during three of the largest net discharges of the 2002-2006 study period (location is shown in Fig. 1)

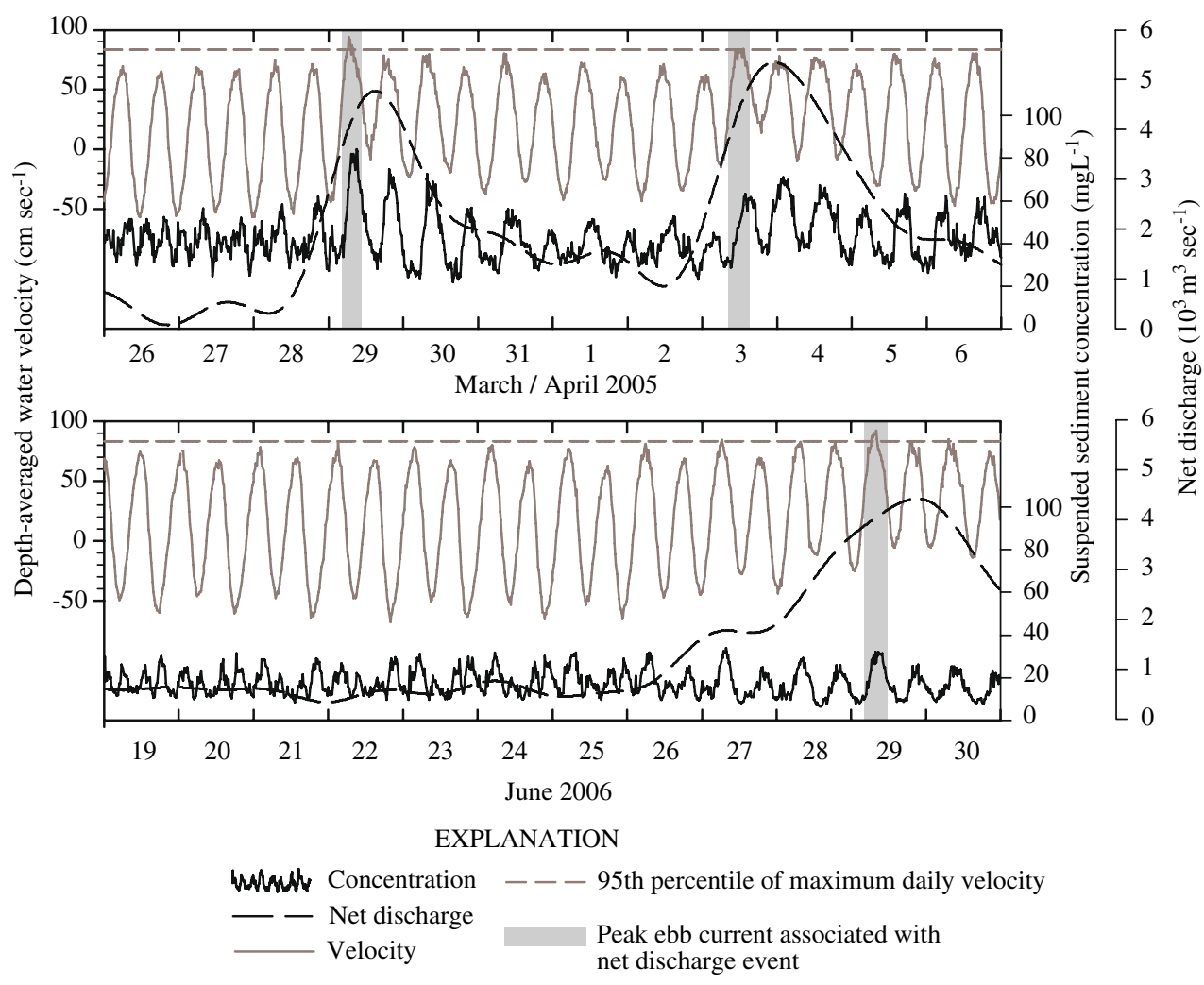

peaks by about $2 \mathrm{~h}$. SSC peaks occur only twice daily during and immediately following tributary high flows; this is because flood-current velocities are dampened during high flows, and the typical flood-current concentration peaks are subsequently absent (Fig. 5). This suggests that over the duration of high flows, the only material moving upriver is that which remains in suspension over slack tide (clay-sized material) and that material settling during slack tide (silt and coarser material) moves only in the downriver direction until the high flow wanes. Ebb-current velocity, conversely, is increased by tributary high flows, which results in greater potential for tidal resuspension; however, sediment supply and the timing of the tributary high flows with respect to lunar and solar gravitational forces appear to be important factors in the magnitude of the resulting concentration. The larger of the two spring freshet events in 2005 (Fig. 5) produced slightly lower ebb velocities and concentrations than the smaller event likely because a neap tide had occurred just a day earlier. Concentrations increased and velocities decreased on successive ebb currents during the April 2005 event (Fig. 5), suggesting that increased amounts of sediment were delivered to the site between ebb flows.

The seasonal pattern in SSC, which is evident in Fig. 4, appears controlled by sediment supply to the estuary. The observed distribution of $15-\mathrm{min}$ ebb and flood velocities at the study site are depicted in Fig. 6. Ebb-current velocity peaks occur in December and June as a result of strengthened tidal forces associated with the solstices; ebb-current velocities are relatively low in September due to the autumnal equinox. Superimposed on this tidal energy is the effect of tributary inflow, which shifts the minimum ebb velocities associated with the vernal equinox from March to February. Similarly, tributary inflow superimposed on the flood current suppresses the winter solstice velocity peak and lower flows in July than June shift the summer solstice velocity peak to July. If unlimited sediment was available for resuspension, it seems reasonable that the concentration pattern would mimic the observed velocity pattern, but the opposite was observed nearly throughout the year on the flood current and during the spring months on the ebb current. The monthly distribution of daily suspended sediment discharge at the Federal Dam is presented with the 15-min concentration data from the study site in Fig. 6. The annual concentration pattern appears much more closely tied with sediment supply than to water velocity, except for the increasing median daily sediment discharge at the Federal Dam from March through April and a decreasing SSC at the study site over the same period.

\section{Suspended Sediment Discharge}

Suspended sediment discharge at the study site over the 4 years totaled $2.95 \times 10^{6}$ metric tons $(\mathrm{t})$; the annual mean was $7.37 \times 10^{5}$ t. The greatest annual sediment discharge 
Fig. 6 Monthly distributions of the maximum daily ebb current (top) and flood current (middle) velocities and the associated concentration of suspended sediment. Monthly distributions of daily suspended sediment discharge (bottom) at the Federal Dam and concentration data observed at the study site (locations are shown in Fig. 1)

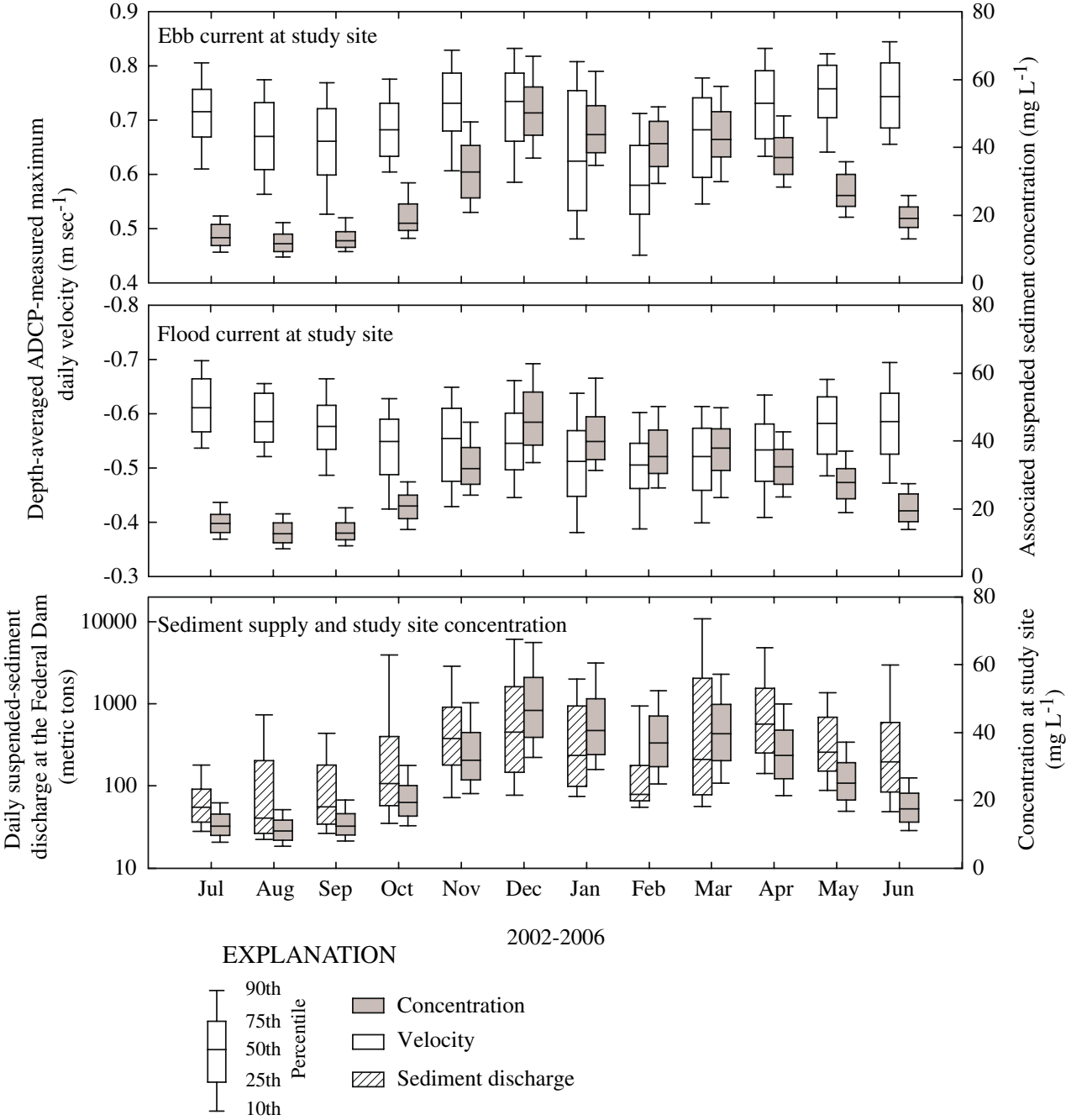

$\left(8.34 \times 10^{5}\right.$ t) occurred in 2005-2006 (year 4), and the lowest annual sediment discharge $\left(6.75 \times 10^{5} \mathrm{t}\right)$ occurred in 2002-2003 (year 1). These values are within a factor of 2 of those determined by Panuzio (1965), Ellsworth (1986),
Howarth et al. (1991), Swaney et al. (1996), and Farley et al. (2003; Table 1). Sediment discharges and yields for this study (the study site, the Hudson River at Waterford, and the Mohawk River at Cohoes) are presented in Table 2.

Table 1 Published values for annual suspended sediment discharge for the lower Hudson River Basin and mean annual discharge at Green Island (Federal Dam), NY, 1963-present

\begin{tabular}{|c|c|c|c|}
\hline Study & $\begin{array}{l}\text { Annual sediment discharge } \\
\text { (metric tons) }\end{array}$ & $\begin{array}{l}\text { Green Island mean } \\
\text { annual discharge }\left(\mathrm{m}^{3} \mathrm{~s}^{-1}\right)\end{array}$ & Notes \\
\hline Panuzio (1965) & $7.25 \times 10^{5}$ & 467 & Sept. 1959-Aug. 1960 at Poughkeepsie, NY \\
\hline Olsen (1979) & $1.02-1.15 \times 10^{6}$ & 483 & 1977 Water Year $^{1} ; 13.8 \mathrm{~km}$ from Battery \\
\hline Ellsworth (1986) & $0.876-1.12 \times 10^{6}$ & NA & $\begin{array}{l}\text { Sediment delivered annually to the lower Hudson } \\
\text { River based on watershed erosion data. }\end{array}$ \\
\hline Howarth et al. (1991) & $4.59 \times 10^{5}$ & 388 & $\begin{array}{l}3 \text { water-year average (1984 to } 1986 \text { ); } \\
\text { sediment delivered to the lower Hudson }\end{array}$ \\
\hline Swaney et al. (1996) & $3.88-5.04 \times 10^{5}$ & 388 & $\begin{array}{l}3 \text { water-year average (1984 to } 1986 \text { ); } \\
\text { sediment delivered to the lower Hudson }\end{array}$ \\
\hline Farley et al. (2003) & $5.86 \times 10^{5}$ & 353 & $\begin{array}{l}4 \text { water-year average }(1989,95,99,2000) \text {; } \\
\text { Hudson watershed input to NY Harbor }\end{array}$ \\
\hline This Study & $7.37 \times 10^{5}$ & 476 & $\begin{array}{l}4 \text { year average (July } 2002-\text { June } 2006 \text { ); } \\
116 \text { river kilometers from Battery (near Poughkeepsie) }\end{array}$ \\
\hline
\end{tabular}

\footnotetext{
${ }^{1}$ One year period from October 1 to September 30; Locations are shown in Fig. 1
} 
Table 2 Sediment discharge and yield in the upper Hudson, Mohawk River, and Study-site drainage basins, 2002-05

\begin{tabular}{|c|c|c|c|c|c|c|}
\hline \multirow[t]{2}{*}{ Year of study } & \multicolumn{2}{|l|}{ Upper Hudson } & \multicolumn{2}{|l|}{ Mohawk } & \multicolumn{2}{|l|}{ Study site } \\
\hline & $\begin{array}{l}\text { Sediment discharge } \\
\left(10^{5} \mathrm{t}\right)\end{array}$ & $\begin{array}{l}\text { Sediment yield } \\
\left(\mathrm{t} \mathrm{km}^{-2}\right)\end{array}$ & $\begin{array}{l}\text { Sediment discharge } \\
\left(10^{5} \mathrm{t}\right)\end{array}$ & $\begin{array}{l}\text { Sediment yield } \\
\left(\mathrm{t} \mathrm{km}^{-2}\right)\end{array}$ & $\begin{array}{l}\text { Sediment discharge } \\
\left(10^{5} t\right)\end{array}$ & $\begin{array}{l}\text { Sediment yield } \\
\left(\mathrm{t} \mathrm{km}^{-2}\right)\end{array}$ \\
\hline 1 & 0.99 & 8.2 & 2.67 & 29.9 & 6.75 & 22.2 \\
\hline 2 & 1.9 & 15.9 & 2.72 & 30.4 & 7.38 & 24.3 \\
\hline 3 & 2.16 & 18.1 & 6.18 & 69.2 & 6.98 & 22.9 \\
\hline 4 & 3.22 & 26.9 & 5.67 & 63.5 & 8.34 & 27.4 \\
\hline
\end{tabular}

Locations are shown in Fig. 1

$t$ metric tons, $t \mathrm{~km}^{-2}$ metric tons per square kilometer

Previously published average sediment yields for the Mohawk River at Cohoes and Hudson at Waterford (Phillips and Hanchar 1996) are within the range observed over of the 4 years of this study. The 4-year sediment contribution to the estuary at the Federal Dam totaled $2.47 \times 10^{6} \mathrm{t}$ for $2002-2006$ of which $36 \%$ occurred in association with three high flow events that dominate the monthly totals of March 2003, April 2005, and June 2006 (Fig. 7). Sediment discharge to the estuary at the Federal Dam, and presumably from tributaries to the freshwater reach as a whole, was disproportionately higher during tributary high-flow events than during other periods, as reflected in the stepwise nature of the cumulative sedimentdischarge curve in Fig. 7. These pulses into the estuary were attenuated by tidal action, however, which results in a smoothed cumulative discharge curve for the study site. Over a seasonal timescale, the slopes of the cumulative curves generally mimic each other with increased slopes in the late fall and spring relative to the summer. The curves diverge over most of the study period with exceptions during, and immediately after, tributary high flows. Despite the high flows in March 2003 and April 2005, the 4-year total suspended sediment discharge for March and April $\left(8.7 \times 10^{4}\right.$ t) was slightly exceeded by the total for November and December over these years $\left(8.8 \times 10^{4} \mathrm{t}\right)$.

The amount of sediment contributed to the estuary at the Federal Dam was matched by a corresponding mass of sediment at the study site within several days or weeks during all but two tributary high-flow events (April 2005 and June 2006). Sediment from the Federal Dam and study sites observed over these periods is not necessarily the same, but a balance was attained between measured inputs to the estuary and exports past the study site within a fairly short period of time. Sediment discharge observations from the Federal Dam and study site during the spring and early summer of 2003-2006 are plotted in Fig. 8. These years present a range of typical spring conditions when rain-onsnowmelt events can produce the largest inputs of sediment and water to the tidal system for a given year; 2003 experienced a modest freshet event, 2004 was without a freshet, 2005 an extreme freshet, and 2006 had no spring freshet until a large rain-only event at the end of June. Following the 2003 freshet in late March, 117\% of the mass observed at the Federal Dam was observed at the study site by the end of June (Fig. 8). The end of June is used as an endpoint here because tidal energy and potential for resuspension decline after this point and thereby increase the potential for sediment entrapment until at least the late fall when net water discharge and tidal velocities increase. Following the 2005 freshet event in early April, only $46 \%$ was observed at the study site by that June (Fig. 8), and $100 \%$ could only be accounted for after 13 months if there was no contribution from the lower Hudson tributaries during this period. This implies that a large amount of
Fig. 7 Monthly totals and cumulative daily suspended sediment discharge observed at the Federal Dam and study site (locations are shown in Fig. 1)

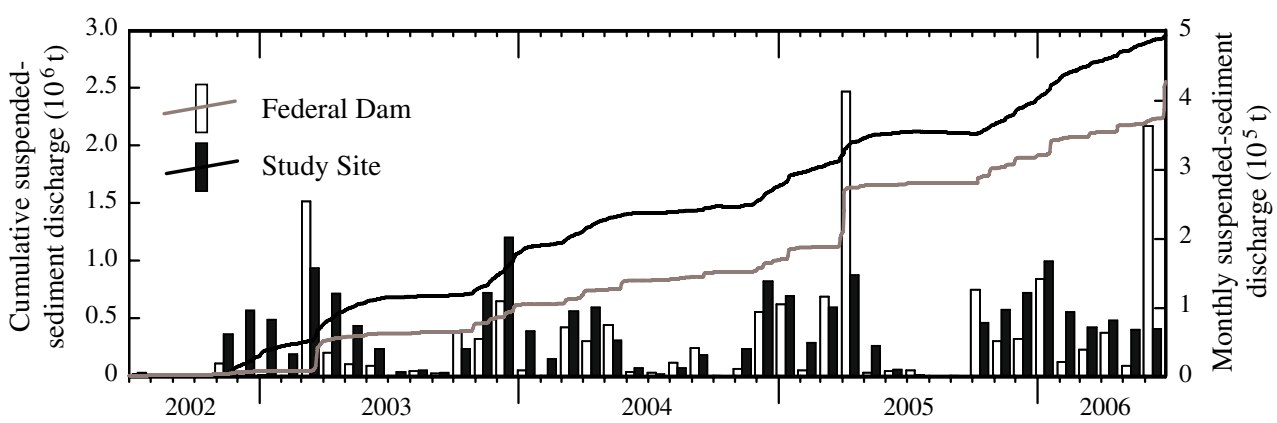




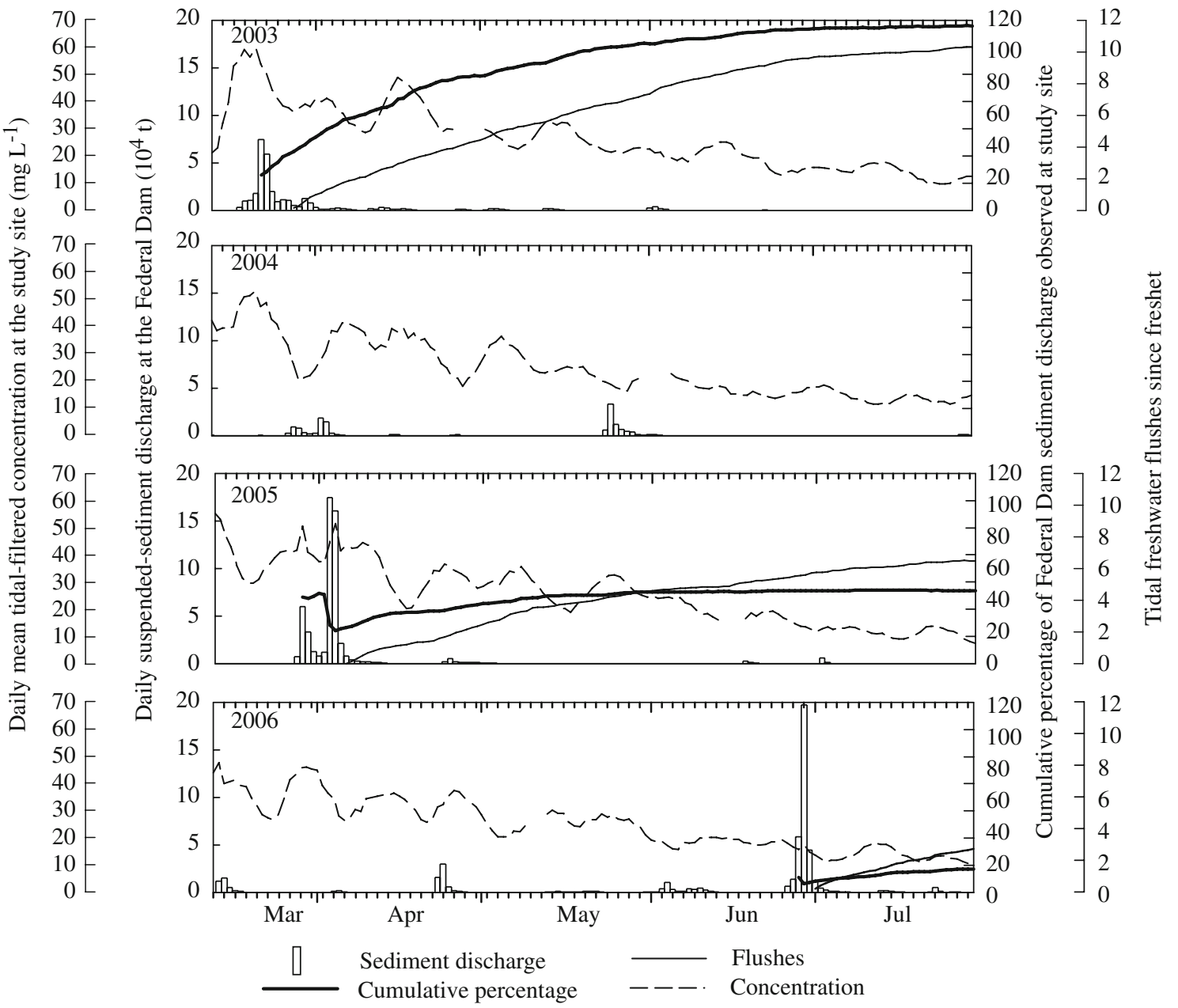

Fig. 8 Daily suspended sediment discharge at the Federal Dam and corresponding percentage of sediment observed at the study site, number of estuary flushes from above the study site, and daily mean tidal-filtered concentration observed at the study site (locations are shown in Fig. 1)

sediment storage, roughly equal to the amount contributed by tributaries over this period, occurred in the freshwater reach above the study site. Significant sediment storage following the June 2006 high flow also appears likely (Fig. 8), although the data are preliminary.

\section{Discussion}

Differences between the percentage of net sediment discharge observed at the study site relative to the Federal Dam after the 2003 and 2005 freshet events (Fig. 8) may be related to: (1) wetter conditions following the 2003 event, that is, the freshwater reach flushed roughly nine times as opposed to six times in the weeks following the 2005 freshet; (2) a smaller and earlier freshet in 2003, that is, there was less material to transport and more time for transport to occur before tidal energy and flushing capacity waned by late June; (3) the likelihood that the 2005 event contributed disproportionately more sand than the 2003 event, much of which became permanently trapped in the freshwater reach. Grain size data from Butch et al. (2001) from the Mohawk at Cohoes and Hudson River at Waterford indicate the percent fines in suspended sediment during most hydrologic conditions, including those observed in 2003 , ranges from $90 \%$ to $95 \%$. Few data on particle size during extreme events are available, but during a February 2000 event on the Mohawk, fines dropped to $80 \%$ at a flow of $2,300 \mathrm{~m}^{3} \mathrm{~s}^{-1}$, slightly less than the peak flows of April 2005 and June 2006 at this site (2,780 and $2,730 \mathrm{~m}^{3} \mathrm{~s}^{-1}$ respectively); therefore, this percentage may have been even lower during these events.

Large net water discharges seem to impart only minimal and short-lived added potential for resuspension at the study site; therefore, the percentage of fines $(96 \pm 3 \%)$ observed at the study site is unlikely to decrease to a value comparable to the Mohawk site during or after an extreme high-flow event. This difference suggests that the competence of the tidal freshwater river at the study site is limited to silt and clay and that coarser material entering the 
freshwater reach during tributary high flows is being trapped upstream from the site. Once in the freshwater reach, these sands do not appear subject to short-duration episodic transport or "leap-frogging" past the study site when seasonal, tide-related, and runoff mechanisms coincide, as evidenced by the absence of bottom sand at the study site and by the downriver fining of river-bottom grain size noted by Coch (1986) and Nitsche et al. (2007) between the mouth of the Rondout River (Fig. 1) and the study site. The relation between sediment discharge from tributaries and at the study site may reverse at water discharges, above a certain threshold in each tributary, at which the transport of sand becomes significant; these water discharges may then result in sediment storage in the freshwater reach, as depicted qualitatively in Fig. 9. Little information exists on sediment transport and grain-size characteristics from tributaries that contribute sediment directly to the freshwater reach, however.

The amount of sediment available for transport at the study site is reflected in the fortnightly amplitude of the mean-daily tidal-filtered concentration. The fact that this amplitude is so small in late June and July when tidal velocities are highest indicates concentration at this time is limited by supply - a condition that may be explained by three possible reasons: (1) most of the sediment that entered the freshwater reach since the previous July has moved past the study site; (2) sediment has settled into long-term storage above the site; and (3) sediment delivered to the freshwater reach in the spring is available for transport but is largely prevented from reaching the study site by a seasonal decline in net water discharge. Probably, some combination of all three possibilities explains the reported observations. The close match between the monthly concentration pattern at the study site and supply pattern from the Federal Dam suggests the lag between sediment delivery to the freshwater reach and transport past the study site is generally on the order of weeks. The observed departure from this pattern during March and April

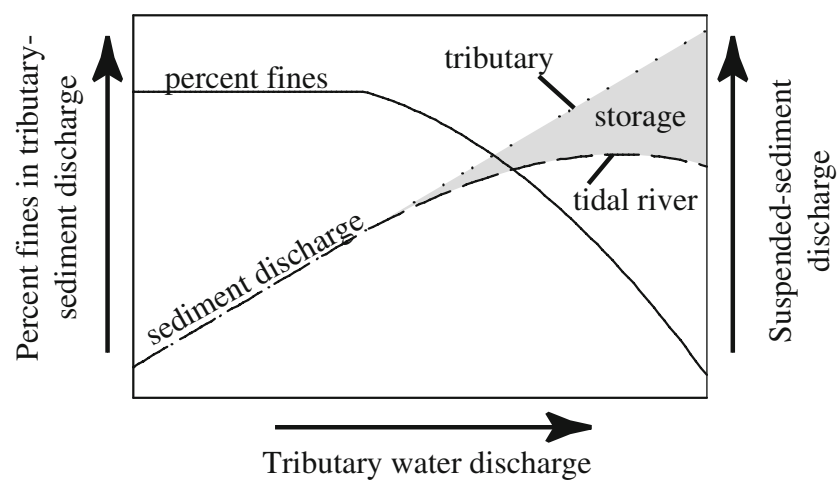

Fig. 9 Relation between tributary discharge, the percentage of fine grained material in suspension, and the amount of sediment discharge exported past the study site probably results from the large amount of sediment delivered to the freshwater reach during this time, together with the timing of the spring freshet relative to the seasonal diminution of net water discharge, which, combined, would result in a longer transport lag to the study site at this time.

The similarity among daily concentration curves for the 4 years depicted in Fig. 8 (dashed lines) despite the lack of a spring freshet in 2004 and the late freshet in 2006 indicates that individual sediment pulses (at least from the Federal Dam) are strongly attenuated by the time they reach the study site. Therefore, much of the sediment flushed from the freshwater reach in 2003 and 2005 (shown in Fig. 8) must have entered the reach in the weeks before the event. Attenuation of sediment pulses entering the estuary combined with a decline in flushing rates at the end of the "flushing season" (October-April) increases the probability of trapping. Sediment associated with a large and late freshet has a high probability of being trapped at least until flushing rates and resuspension potential increase in the fall.

Similar to a late season spring freshet, the runoff associated with a hurricane may result in net storage of sediment, depending on its timing and magnitude. As with the June 2006 event, a hurricane would deliver a large amount of sediment to the freshwater reach, but water discharge and flushing rates may diminish before sediment delivery to and past the study site. As a result, the sediment discharge at the study site would reflect the combination of the preexisting seasonal sediment concentration and the net water discharge associated with the event. A subsequent return to normal (seasonal) flushing rates before sediment delivery to the study site would result in at least short-term trapping of sediment associated with the event. A November hurricane of comparable size would produce a larger sediment discharge simply because late-fall concentrations are higher than those in the summer; furthermore, higher flushing rates during the fall would decrease the potential for short-term storage.

The general divergence of the cumulative 2002-2006 sediment-discharge curves for the study site and the Federal Dam (Fig. 7), which indicate substantially greater sediment discharge at the study site than at the Federal Dam, may have three possible explanations: (1) tributary sediment discharge to the freshwater reach above the study site, (2) erosion of sediment from storage in the same reach, and/or (3) bias introduced by differences between the data collection methods used to compute sediment discharge at the Federal Dam and the study site. The erosion of significant amounts of sediment from long-term storage during the 4-year period appears unlikely in that net deposition, rather than net erosion, was observed during extreme tributary high flows, and the study site appears sediment-limited during periods of the year when the 
potential for resuspension was greatest. Cumulative sediment discharge at the Federal Dam was $86 \%$ of that observed at the study site over the 4-year period, although $11 \%$ of this difference was due to the June 2006 pulse that occurred 2 days before the end of the study period. In addition, some unknown percentage of the April 2005 highflow event went into storage, lowering this percentage further. The cumulative sediment discharge at the Federal Dam before the April 2005 event (the first event where a significant amount of sediment apparently went into storage) was lower- $60 \%$ of that at the study site - an amount close to the percentage of Hudson River drainage that lies above the Federal Dam (69\%). If the Sacandaga and Ashokan Reservoirs (Fig. 1) are considered as sediment traps, this percentage drops slightly $(67.5 \%)$. The above considerations suggest that the discrepancy between the two sediment curves (Fig. 7) is probably due to tributary inflow, although the possibility of some bias related to differing sampling methods cannot be ruled out. Model output from Swaney (1996), which incorporates differences in land use across the watershed, suggests that sediment yield for the lower Hudson is greater then the upper Hudson; this is consistent with the possibility that $32.5 \%$ of the watershed accounts for approximately $40 \%$ of the sediment discharge. Attributing $30 \%$ to $40 \%$ of the sediment discharge at the study site to contributions from tributaries between the Federal Dam and study site supports the suggestion of Chilrud et al. (2004), based on the geochemical dilution of Hudson River bottom sediments, of a significant sediment source entering the freshwater reach between the Federal Dam and Rondout River.

A simple model of sediment entering the freshwater reach and passing through on a timescale of weeks appears reasonable during normal hydrologic conditions in adjoining watersheds. However, the attenuation and possible storage of sediment associated with extremely high flows, especially those at the end of, or after, the "flushing season", can result in considerably smaller exports than predicted by this simple model. Therefore, previous values of annual or seasonal sediment delivery from tributaries and the Federal Dam to the ETM and harbor may be overestimated for those years with extreme tributary high-flow events. For example, Woodruff et al. (2001) noted a sediment deficit of $2.2 \times 10^{5} \mathrm{t}$ between mass loading at the ETM and estimates of sediment discharge at the Federal Dam after the 1998 freshet and suggested trapping above the ETM, an observation similar to that for the April 2005 high flow in the present study.

Although the study duration of 4 years is likely too small to represent the full range in annual sediment discharge at the study site, the observed sediment attenuation and/or trapping may explain the small range in annual sediment discharge relative to other multi-year estimates based on tributary inflow (Woodruff 1999; Farley et al. 2003). The range of estimates from these studies is largely driven by extreme tributary high flows in a given year, which typically contribute a disproportionate amount of sediment relative to the remainder of the year; for example, the March and April 2005 high flows on the Mohawk River contributed $38 \%$ of the annual sediment discharge for the Mohawk River at Cohoes for year 3 of this study. It is unclear if the shift toward wetter conditions in the fall (Fig. 3) will persist, but these conditions likely contributed to a shift away from the spring and toward the fall and winter months for the timing of the bulk of sediment delivered from the freshwater reach, a shift that further complicates simple models of sediment delivery.

\section{Conclusions}

Suspended sediment discharge from the freshwater reach of the Hudson River estuary to the study site near Poughkeepsie, from July 2002 to June 2006, averaged 737,000 t annually. The seasonal patterns of suspended sediment concentration at the study site, $130 \mathrm{~km}$ downstream from the Hudson head-of-tide at the Federal Dam, was paralleled more closely by inputs from the head-of-tide than by river velocity, suggesting that the freshwater reach, or at least the study site, was sediment-limited during summer months when river velocity and subsequent potential for tidal resuspension was highest. Extreme tributary runoff events may result in proportionately less sediment exported from the tidal freshwater reach than non-extreme events due to the lack of competence in the reach in transporting sands past the study site. The timing of extreme events may also result in at least temporary storage of sediment in the reach if these events occur late or beyond the "flushing season" between October and April. After accounting for storage, approximately $30-40 \%$ more sediment was exported from the tidal freshwater reach than entered the Hudson head-oftide, suggesting lower Hudson tributaries are significant sources of suspended sediment.

Acknowledgments Thanks are extended to Fran Dunwell and the New York State Department of Environmental Conservation's Hudson River Estuary Program for partial support of this work, and to Richard Bopp, Rocky Geyer, and two anonymous reviewers for reviews and suggestions.

\section{References}

Abood, K.A. 1974. Circulation in the Hudson Estuary. Annals of the New York Academy of Sciences 250: 39-111.

Butch, G.K., P.M. Murray, T.P. Suro, and J.F. Weigel. 2001. Water resources data New York-Water year 2000 vol. 1 Eastern New 
York excluding Long Island. US Geological Survey Water-Data Report NY-00-1. Virginia: Reston.

Busby, M.W., 1966. Flow, quality and salinity in the Hudson River estuary. Symposium on Hudson River Ecology, ed. M. Eisenbud, and D. B. Stevens, 135-146. Hudson River Valley Commission of New York.

Center for Operational Oceanographic Products and Services. 2007. Tidal station locations and ranges, accessed January 16, 2007 at http://tidesandcurrents.noaa.gov/tides07/tab2ec2a.html.

Chillrud, S.N., R.F. Bopp, J.M. Ross, D.A. Chaky, S. Hemming, E.L. Shuster, H.J. Simpson, and F. Estabrooks. 2004. Radiogenic lead isotopes and time stratigraphy in the Hudson River, NY. Water, Air, and Soil Pollution: Focus 4: 469-482.

Coch, N.K. 1986. Sediment characteristics and facies distributions in the Hudson system. Northeastern Geology 8: 141-155.

Cooper, J.C., F.M. Cantelmo, and C.E. Newton. 1988. Overview of the Hudson River Estuary. American Fisheries Society Monograph 4: $11-24$.

Darmer, K.I. 1969. Hydrologic characteristics of the Hudson River Estuary. In Second Symposium on Hudson River Ecology, eds. G. P. Howell, and G. J. Lauer, 40-55. Albany, New York: New York State Department of Environmental Conservation.

Ellsworth, J.M. 1986. Sources and sinks of fine-grained sediment in the lower Hudson River. Northeastern Geology 8: 141-155.

Farley, K., R. Miller, J. Wands, and D. Damiani. 2003. Inventory of sediment loads to the Lower Hudson and NY-NJ Harbor. Abstracts of the Hudson River Foundation Sediment Transport Workshop, November 20, 2003.

Geyer, W.R., and R. Chant. 2006. The physical oceanography processes in the Hudson River estuary. In The Hudson River estuary, eds. J. S. Levinton, , and J. R. Waldman, 24-38. New York City, USA: Cambridge University Press.

Geyer, W.R., J.D. Woodruff, and P. Traykovski. 2001. Sediment transport and trapping in the Hudson River Estuary. Estuaries 24: 670-679.

Helsel, D.R. and R.M. Hirsch. 1992. Statistical methods in water resources. Amsterdam: Elsevier Science B.V. v. 49

Howarth, R.W., J.R. Fruci, and D. Sherman. 1991. Inputs of sediment and carbon to an estuarine ecosystem: influence of land use. Ecological Applications 1: 27-39.

Lodge, J.M. 1997. A model of tributary sediment input to the tidal Hudson River. MS thesis, State University of New York at Stony Brook, Stony Brook, New York.

Nitsche, F.O., W.B.F. Ryan, S.M. Carbotte, R.E. Bell, A. Slagle, C. Bertinado, R. Flood, T. Kenna, and C. McHugh. 2007. Regional patterns and local variations of sediment distribution in the Hudson River Estuary. Estuarine, Coastal and Shelf Science 71: 259-277.
Olsen, C.R. 1979. Radionuclides, sedimentation and the accumulation of pollutants in the Hudson River Estuary. PhD Thesis. New York, New York: Columbia University.

Panuzio, F.L. 1965. Lower Hudson River siltation. Proceedings of the 2nd Federal Interagency Sedimentation Conference. p. 512-550. Agricultural Research Service, Misc. Publication 970.

Phillips, P.J. and D. Hanchar. 1996. Water-quality assessment of the Hudson River Basin in New York and adjacent states. US Geological Survey Water-Resources Investigations Report 964065. Reston, Virginia.

Port Authority of NY/NJ. 1995. Economic impact of the port industry on the New York-New Jersey metropolitan region. Report to the Port Department from the Economic Impacts Division, Office of Economic and Policy Analysis Port Authority of New York \& New Jersey.

Potterfield, G. 1972. Computation of fluvial-sediment discharge. US Geological Survey, Techniques of Water Resources Investigations, chapter C3. Reston, Virginia.

Randall, A.D. 1996. Mean annual runoff, precipitation, and evapotranspiration in the glaciated northeastern United States, 195180. US Geological Survey Open-File Report 96-395, scale $1: 1,000,000,2$ sheets.

Swaney, D.P., D. Sherman, and R.W. Howarth. 1996. Modeling water, sediment and organic carbon discharges in the Hudson-Mohawk basin: coupling to terrestrial sources. Estuaries 19: 833-847.

Traykovski, P., R. Geyer, and C. Sommerfield. 2004. Rapid sediment deposition and fine-scale strata formation in the Hudson Estuary. Journal of Geophysical Research 109: F02004.

US Geological Survey. 1999. National field manual for the collection of water quality data. US Geological Survey Techniques of Water Resources Investigations, Book 9, chapter A4. Reston, Virginia.

US Geological Survey. 2006. Water resources data New York-Water year 2005 vol. 1 Eastern New York excluding Long Island. US Geological Survey Water-Data Report NY-05-1, accessed February 23, 2007 at http://ny.water.usgs.gov/pubs/wdr/wdrny051/.

Wall, G.R., E.A. Nystrom, and S. Litten. 2006. Use of an ADCP to compute suspended-sediment discharge in the tidal Hudson River, New York. US Geological Survey Scientific Investigations Report 2006-2055. Reston, Virginia.

Woodruff, J.D. 1999. Sediment deposition in the lower Hudson River Estuary. Master's thesis, Massachusetts Institute of Technology/ Woods Hole Oceanographic Institution. Massachusetts, Woods Hole.

Woodruff, J.D., W.R. Geyer, C.K. Sommerfield, and N.W. Driscoll. 2001. Seasonal variation of sediment deposition in the Hudson River estuary. Marine Geology 179: 105-119. 